\title{
Domestication of Terminalia brownii Among Smallholder Farmers in Eastern Kenya: A Double Hurdle Approach.
}

\author{
Albert, M. Luvanda ${ }^{1 *} \quad$ Christopher, N. Kamau ${ }^{2} \quad$ Sylvia, M. Uchi ${ }^{1} \quad$ Pauline Bala $^{3}$ \\ Michael M. Okeyo ${ }^{1}$ \\ 1.Kenya Forestry Research Institute (KEFRI), Dryland Eco-Region Research Programme (DERP) - Kitui. P.O \\ BOX 892, Kitui, Kenya \\ 2.Department of Agricultural Economics, Kenyatta University P.O BOX 43844, Nairobi \\ 3.Kenya Forestry Research Institute (KEFRI), Rift Valley Eco Region Research Programme (LVRP), Turbo Sub \\ Centre, P.O. Box 5 Turbo Kenya
}

The research is financed by National Research Fund, Kenya

\section{Abstract}

Evidence has shown that the population of Terminalia brownii continue to dwindle in its native range due to drought, agricultural expansion and settlement and over exploitation for charcoal, beehives, carvings and timber. High levels of exploitation accompanied by awareness creation on value addition remains an exit strategy towards poverty alleviation for improved rural livelihoods, hence, the need to support its domestication. Scientists and researchers have prioritized promotion of this species in Eastern Kenya. However, information on intensity of domestication of the species remained scanty. A sample of 346 T. brownii producers were selected using a multistage sampling procedure in Embu, Machakos, Kitui and Makueni Counties in Kenya. Primary data was collected using a pretested structured questionnaire while secondary data was acquired from the Kenya Forest Service offices in the study area. A double hurdle econometric model was used to analyse the determinants of decision and intensity of use of $T$. brownii. Results revealed that five variables that significantly influence the decision to domesticate T. brownii include; education level of household head, importance of farm to the household income, access to credit, dependency ratio and intercropping. On the other hand, education of the household head, size of the farm and total income from livestock sales influenced intensity of domestication of $T$. brownii. Therefore, there is need to develop programs to sensitize farmers on the importance of the species on their farms. Lastly, we need to promote structures for commercialization of the agroforestry products from this tree species to reduce unemployment.

Keywords: Terminalia brownii, Domestication, Agroforestry, Dryland, Double Hurdle

DOI: $10.7176 / \mathrm{JESD} / 10-16-07$

Publication date: August $31^{\text {st }} 2019$

\section{Introduction}

Smallholder farmers have often been blamed for being the main cause of deforestation since as they gain access to forests after logging companies have harvested timber or partially converted the natural forest to other uses. Furthermore, the role of smallholder farmers as agents of reforestation is usually not acknowledged. As local forest resources disappear, smallholder farmers protect and plant on farm trees for subsistence and income purposes. The scarcity of forests or tree products provides farmers with an opportunity to diversify farm production and income streams. The rapidly increasing population significantly contributes to deforestation as farmers strive to meet their requirements for fuelwood, building materials and clearing for agricultural land. As access to forest products dwindles, an increasingly higher proportion of households are finding it necessary to explore options to domesticate trees and shrubs in their small farms (James et al., 2000).

Majority of smallholder farmers within the tropics rely on various indigenous tree species including Terminalia brownii (Fresen) as a secure source of livelihood (Neufeldt et al., (2012). Studies have revealed that forest goods and services provide security for over $80 \%$ of the smallholder farmers thus contributing to poverty reduction and national development (Nasi et al., 2008). Further, indigenous trees mitigates soil erosion menace in many of the developing countries in Africa (Mutegi et al., 2008; Ma et al., 2009) thus addressing the vulnerability to negative climate impacts (Garnity et al., 2010). According to Sileshi et al., (2011), conservation of trees helps improve on grain production thus addressing food insecurity. Trees have been found to generate good returns hence impacting on poverty alleviation among the rural households (CIE, 2011). Many indigenous tree species that provide fruits, medicine, oils, beverages, timber, firewood, charcoal and other industrial raw materials remain largely wild. This implies that there is a huge potential for rural communities to increase their income streams through domestication of indigenous specific tree species. Therefore, domestication remains an avenue of addressing the negative climatic hazards through food and income diversification (Thorlakson and Neufeldt, 2010; Altieri et al., 2015). Furthermore, promoting trees growing positively improves on nutrition of the inhabitants especially in Sub-Saharan Africa (Von et al., 2014: Covic and Hendriks, 2016 \& FAO, 2017). Notably, prioritizing tree domestication has been identified as a new frontier towards science based agroforestry 
development which will apparently translate to achievement of Millennium Development Goals (MDGs) (FAO, 2017).

Terminalia brownii is an indigenous tree species that usually grown to a height of $4-15 \mathrm{~m}$ high and its widely distributed in high rainfall woodlands, bushlands, and wooded savannah of the arid and semi-arid lands of Africa (Mosango, 2013, Orwa et al., 2009). It is a fast growing, drought tolerant and termite resistant species in Combritaceae family. It is a deciduous tree native to Eritrea, Ethiopia, Kenya, Somalia, Sudan, Tanzania, Republic of Congo and Uganda (Maundu and Tengnas, 2005; Orwa et al., 2009; Mbwambo et al, 2007, Machumi et al. 2013, Mbiri et al, 2016; Francis et al., 2013, Asmait et al, 2018). The distribution is influenced by temperature, rainfall and soil conditions (Schmidt, 2010; Enass, 2017). The species thrives well in deep, sandy and loam soils with mean annual rainfall of 500 to $1300 \mathrm{~mm}$. In Kenya, the tree grows in agro-ecological zones such as; zone III, and IV. It flowers from March to June under normal climatic conditions. In its natural range, it is known as shagarat elsobag in Sudan, Leh heli (Boni), Biress (Boran), Muuku, muvuku or Kiuku (Kamba), Mbambaro/ mbarao or mwalambe (Kiswahili), koloswa (northern region, Kenya), weba (Ethiopia), lbukoi (Samburu), orbukoi (Maasai, Tanzania) (Thoria et al., 2011; Mbwambo et al, 2007; Maundu, and Tengnas, 2005).

Terminalia brownii is a multipurpose species that is widely used in construction and joinery works. It is mainly used as a source of high quality fuelwood for domestic, tobacco curing and drying and brick making (Orwa et al., 2009; ICRAF, 1992). Alternatively, the wood is used for furniture making, fencing posts, canoes/boat building, carvings (utensils, bowls, spindles, moldings, etc.) tool handles, beehives, walking sticks, coffin boards, beams, rafters/ foundation piles, joists, flooring, handcarts, shuttles, veneer and plywood, (ICRAF, 1992; Maundu and Tengnas, 2005; Mosango, 2013). According to Neufeldt et al., (2012), the study supported the use of the species for timber and medicinal purposes. The human, crop and livestock medicine derived from $T$. brownii for treatment of bacterial, fungal and viral infections exceeds that of conventional drugs by 2-3 times (Mbiri et al, 2016; Kigen et al, 2013; Pal and Shukla, 2003). Furthermore, it is used alone or in combination with other plants for medicinal purposes. It is used to treat cough, jaundice, malaria, diarrhea, cut wounds, hepatitis, liver cirrhosis, yellow fever, tuberculosis, epilepsy, urino-genital problems, syphilis, gonorrhoea, body swellings, heartburn, stomach complaints, colic, eye infections, tonsillitis, typhoid, endometriosis, cystitis, leucorrhoea, snake bites and ring worm (Mbiri et al, 2016, Kareru, et al., 2007; Enass et al., 2017; Mbwambo et al., 2007; Khalid et al., (2007; Kidane et al,. 2014).

Terminalia brownii water extracts are sprayed on wooden houses and furniture to protect them against insect attack (Salih et al., 2017). Other uses include provision of tannin, dye, shelter perfume, fodder, bee forage, soil improvement, shade and ornamental (Mosango, 2013; Mbwambo, et al., 2007; Machumi et al, 2013 and Zakaria et al., 2017). Therefore, T. brownii, contribute immensely to improving livelihood through domestic and cottage industry. Terminalia brownii is well adapted to the ecological conditions due to their drought tolerance nature and increasing importance in mitigating climate change, improving land productivity and provide an opportunity for commercial/industrial growth of the inhabitants in dry lands (Awodoyin et al., 2015). However, domestication of T. brownii under an agroforestry system is hindered by lack of information on domestication which this study seeks to address.

\section{Study site, data and sampling procedure}

This study was conducted in Embu (Mbeere North and South), Machakos (Mwala), Makueni (Wote) and Kitui (Kitui south) counties which were purposively selected due to high T. brownii abundance in semi-arid farming zone, semi-arid ranching areas, arid-agro-pastoral area and arid-pastoral zone. Low rainfall and temperatures in these counties hinder rain-fed crop production making commercial tree production $r$ to remain a top priority. A total sample of 346 respondents were sampled and interviewed in the four study sites. The respondents were distributed across Makueni ( $\mathrm{n}=98)$, Machakos $(\mathrm{n}=85)$, Embu $(\mathrm{n}=83)$ and Kitui $(\mathrm{n}=80)$ representing 28\%, 25\%, 24\% and $23 \%$ of the total respondents, respectively. The respondents were sampled using a multi-stage random sampling procedure. Primary data was collected using structured questionnaire, photography and direct observation. Secondary data was acquired from reports, journals and Kenya Forest Service records. The collected data was coded and entered into computer using an Excel Microsoft Office. Data was then cleaned using conditional formatting to check for outliers and duplicates values. The cleaned data was exported to STATA Software Version 13 for analysis. The explanatory variables were checked for multi-collinearity using correlation and Variance Inflation Factor (VIF) analysis. As a rule of thumb, if the VIF of a given variable is more than 10 and the R2 exceeds 0.90 , then the variable is said to be highly collinear.

\section{Specification of the Model and Analytical Framework}

A Double Hurdle approach was used to analyse the data. It is a parametric generalization of Tobit model developed by Cragg, (1971). The two tier model is also referred to us censored regression models. First the models define participation or decision stage by the use of a discrete dependent variable $\left(y^{*}=0, y=1\right)$. The second model is conditional on the result of the first stage. Tobit model assumes that the factors which influence the decision to 
participate are the same factors that influence the intensity of participation. The assumptions of the Tobit model are relaxed by a double hurdle model that assumes different factors affect the decision of participation/adoption and the level of participation/adoption. According to Cragg (1971), adoption is faced by 2 tiers. The first is whether to domesticate or not to domesticate $T$. brownii and second stage is related to intensity of domestication. The relationship between the two tiers is hypothesized to be linked (Berhanu and Swinton, 2003). Therefore, various recent studies have been used to analyse this hypothetical relationship (Asfaw et al., 2011, Kuti, 2015; Gebremichael and Gebremedhin, 2014; Katengeza et al., 2012; Akpan et al., 2011 \& Mal et al., 2012).

The 2-tiers model specifications by Cragg (1971) are represented as follows:

$$
\begin{aligned}
& D{ }_{i}=\alpha Z_{i}+V_{i} \\
& Y^{*}=\beta X_{i}+U_{i}
\end{aligned}
$$

Where $\mathrm{D}_{\mathrm{i}}=\left\{1\right.$, if $\mathrm{D}_{\mathrm{i}}^{*}>0 ; 0$ if $\left.\mathrm{Di}^{*} \leq 0\right\}$ and $\mathrm{Y}_{\mathrm{i}}=\left\{\mathrm{Y}^{*}\right.$, if $\mathrm{Y}_{\mathrm{i}}>0$ and $\mathrm{Di}^{*}>0 ; 0$, if otherwise $\}$

$\mathrm{D}_{\mathrm{i}}^{*}$ - latent variable that makes the value 1, if the farmer domesticates Terminalia brownii; 0 otherwise.

$\mathrm{Z}_{\mathrm{i}}-$ Vector of household characteristics explaining domestication decision

$\mathrm{X}_{\mathrm{i}}$ - Vector explaining the level of domestication and $\mathrm{U}_{\mathrm{i}}$ and $\mathrm{V}_{\mathrm{i}}-$ Stochastic terms.

The number of T. brownii trees was used to determine the intensity of domestication in the second hurdle of Craggs model.

The log likelihood function for the double-hurdle model is represented by equation below.

$$
\log L=\sum_{/ 0} \ln \left[1-\phi\left(\alpha Z_{i}^{\prime}\right)\left(\frac{\beta \mathrm{X}_{i}^{\prime}}{\sigma}\right)\right]+\sum_{/+} \ln \left[\phi\left(\alpha Z_{i}^{\prime}\right) \frac{1}{\sigma} \varphi\left(\frac{Y_{i-} \beta X_{i}^{\prime}}{\sigma}\right)\right] \ldots \text { (3) }
$$

Where $\Sigma / 0=$ summation over the zero observations; $\Sigma /+$ stands for summation over positive observations; and $\phi$ and $\varphi$ are the standard normal cumulative distribution functions and probability distribution functions respectively.

\section{Results and Discussions}

Socio-economic characteristics of the smallholder Terminalia brownii farmers in Eastern Kenya

The descriptive statistics describing the socio-economic characteristics of sampled households constitutes

\begin{tabular}{|c|c|c|c|c|c|c|}
\hline Variable & County & $\begin{array}{l}\text { Embu } \\
N=83\end{array}$ & $\begin{array}{l}\text { Kitui } \\
\mathbf{N}=\mathbf{8 0}\end{array}$ & $\begin{array}{l}\text { Mach } \\
\text { N=85 }\end{array}$ & $\begin{array}{l}\text { Maku } \\
\text { N =98 }\end{array}$ & $\begin{array}{l}\text { Pooled } \\
\mathrm{N}=346\end{array}$ \\
\hline \multirow{2}{*}{$\begin{array}{l}\text { Age of Household } \\
\text { Head }\end{array}$} & Mean & 52.88 & 54.30 & 57.79 & 56.48 & 55.43 \\
\hline & $\begin{array}{l}\text { Std. Dev } \\
\chi^{2} \\
\text { P-Value }\end{array}$ & $\begin{array}{l}15.003 \\
3.514 \\
0.319\end{array}$ & 17.30 & 14.19 & 15.21 & 15.48 \\
\hline \multirow[t]{4}{*}{ Household Size } & Mean & 5.24 & 5.96 & 5.247 & 5.07 & 5.36 \\
\hline & Std. Dev & 1.75 & 2.48 & 2.154 & 2.37 & 2.22 \\
\hline & & 10.41 & & & & \\
\hline & P-Value & $0.015 * *$ & & & & \\
\hline \multirow[t]{4}{*}{ Farm Size } & Mean & 4.298 & 5.902 & 4.779 & 8.420 & 5.955 \\
\hline & Std. Dev & 4.141 & 5.077 & 3.378 & 8.479 & 5.975 \\
\hline & & 89.12 & & & & \\
\hline & P-Value & $0.000 * * *$ & & & & \\
\hline \multirow{4}{*}{$\begin{array}{l}\text { Tropical Livestock Unit } \\
\text { (TLU) }\end{array}$} & Mean & 3.217 & 5.081 & 4.356 & 5.487 & 4.571 \\
\hline & Std. Dev & 3.716 & 4.885 & 2.970 & 3.986 & 4.014 \\
\hline & & 20.16 & & & & \\
\hline & P-Value & $0.000 * * *$ & & & & \\
\hline \multirow{4}{*}{ Total Income Livestock } & Mean & 7079 & 9607 & 12254 & 22073 & 13182 \\
\hline & Std. Dev & 1715 & 1741 & 3399 & 5738 & 3716 \\
\hline & & 170.7 & & & & \\
\hline & P-Value & $0.000 * * *$ & & & & \\
\hline \multirow{4}{*}{ Dependency Ratio } & Mean & 90.995 & 115.56 & 66.73 & 136.47 & 103.60 \\
\hline & Std. Dev & 101.96 & 174.65 & 99.36 & 132.85 & 132.42 \\
\hline & & 35.39 & & & & \\
\hline & Pr-Value & $0.000 * * *$ & & & & \\
\hline
\end{tabular}
variables, mean, standard deviation and Chi square-test.

Table 1: Description of dependent and independent variables

Source, Survey Data, (2018)

The mean age of the household head was 55.43 years. These findings suggest that the sampled household falls under the economically active members of the community. The findings revealed that there was a significant difference at 5\% on household size. Approximately, there were five (5) members per household (Table 1). 
However, posthoc tests (Tukey Test) depicts that households in Kitui comprised of more members as compared to Makueni. The farm sizes ranged between 4.298 to 8.42 acres. Embu and Makueni had the lowest and highest landholdings, respectively. Results from the pooled mean on land size revealed that landholding for the households in Embu and Machakos was lower. In contrast to Makueni County, there was a significant difference (Appendix 3). Tropical Livestock Unit (TLU) was computed using the various recommended bi-weights to quantify on the TLU Index. Households in Makueni reared more livestock as compared to Kitui, Machakos and Embu. This finding depicts that farmers in Makueni do practice livestock production as their major economic activity. Correlation analysis revealed a positive relationship between land size and the tropical livestock unit (Appendix 2). Previous reports indicates that majority of smallholder farmers in Makueni are dependent on livestock due to frequent crop failure witnessed in the area. The total dependency ration was high for Makueni as compared to other counties. However, Machakos County was reported to have had the lowest dependency ration of $66.73 \%$. This inter county variation was statistically significant at 1\% (Table 1). This implies that majority of the respondents in Makueni county were economically inactive.

Table 2 presents the totals, proportions and F-Test derived from Analysis of Variance (ANOVA) of the dummy variables of the sampled households. Participation in social group and access to credit for farm operations revealed significant differences between the counties. The Bartlett's test for equal variances for the two variables showed statistical significance at $1 \%$.

Table 2: Descriptive statistics for binary variables of the sampled households

\begin{tabular}{|c|c|c|c|c|c|c|c|}
\hline Variable & $\begin{array}{l}\text { Count } \\
\mathbf{y}\end{array}$ & $\begin{array}{l}\text { Embu } \\
(\mathrm{N}=\mathbf{8 3})\end{array}$ & $\begin{array}{l}\text { Kitui } \\
(\mathbf{N}=\mathbf{8 0})\end{array}$ & $\begin{array}{l}\text { Machako } \\
\text { s } \\
(\mathrm{N}=85)\end{array}$ & $\begin{array}{l}\text { Makueni } \\
(\mathrm{N}=98)\end{array}$ & $\begin{array}{l}\text { Total } \\
(\mathrm{N}=346)\end{array}$ & $\begin{array}{l}\text { Prob> } \\
\text { F }\end{array}$ \\
\hline \multirow[b]{2}{*}{$\begin{array}{l}\text { Gender } \\
\text { head }\end{array}$} & Female & $22(6.4 \%)$ & $30(8.7 \%)$ & $24(6.9 \%)$ & $25(7.2 \%)$ & $\begin{array}{l}101 \\
(29.2 \%)\end{array}$ & \multirow[b]{2}{*}{0.768} \\
\hline & Male & $\begin{array}{l}61 \\
(17.6 \%)\end{array}$ & $\begin{array}{l}50 \\
(14.5 \%)\end{array}$ & $\begin{array}{l}61 \\
(17.6 \%)\end{array}$ & $\begin{array}{l}73 \\
(21.1 \%)\end{array}$ & $\begin{array}{l}245 \\
(70.8 \%)\end{array}$ & \\
\hline \multirow[b]{2}{*}{ On-farm Participation } & Yes & $\begin{array}{l}72 \\
(20.8 \%)\end{array}$ & $\begin{array}{l}66 \\
(19.1 \%)\end{array}$ & $\begin{array}{l}78 \\
(22.5 \%)\end{array}$ & $\begin{array}{l}88 \\
(25.4 \%)\end{array}$ & $\begin{array}{l}304 \\
(87.9 \%)\end{array}$ & \multirow[b]{2}{*}{0.3836} \\
\hline & No & $11(3.2 \%)$ & $13(3.8 \%)$ & $7(2 \%)$ & $10(2.9 \%)$ & $41(11.8 \%)$ & \\
\hline \multirow[b]{2}{*}{ Group Membership } & Yes & $\begin{array}{l}41 \\
(11.8 \%)\end{array}$ & $\begin{array}{l}59 \\
(17.1 \%)\end{array}$ & $\begin{array}{l}43 \\
(12.4 \%)\end{array}$ & $\begin{array}{l}71 \\
(20.5 \%)\end{array}$ & $\begin{array}{l}214 \\
(61.8 \%)\end{array}$ & \multirow[b]{2}{*}{0.0002} \\
\hline & No & $\begin{array}{l}42 \\
(12.1 \%)\end{array}$ & $21(6.1 \%)$ & $\begin{array}{l}42 \\
(12.1 \%)\end{array}$ & $27(7.8 \%)$ & $\begin{array}{l}132 \\
(38.2 \%)\end{array}$ & \\
\hline \multirow[b]{2}{*}{ Access to Credit } & Yes & $14(4 \%)$ & $3(0.9 \%)$ & $3(0.9 \%)$ & $1(0.3 \%)$ & $21(6.1 \%)$ & \multirow[b]{2}{*}{0.000} \\
\hline & No & $\begin{array}{l}69 \\
(19.9 \%)\end{array}$ & $\begin{array}{l}77 \\
(22.3 \%)\end{array}$ & $\begin{array}{l}82 \\
(23.7 \%)\end{array}$ & $97(28 \%)$ & $\begin{array}{l}325 \\
(93.9 \%)\end{array}$ & \\
\hline \multirow[b]{2}{*}{ Off-farm participation } & Yes & $33(9.5 \%)$ & $27(7.8 \%)$ & $\begin{array}{l}39 \\
(11.3 \%)\end{array}$ & $38(11 \%)$ & $\begin{array}{l}137 \\
(39.6 \%)\end{array}$ & \multirow[b]{2}{*}{0.462} \\
\hline & No & $\begin{array}{l}50 \\
(14.5 \%)\end{array}$ & $\begin{array}{l}53 \\
(15.3 \%)\end{array}$ & $\begin{array}{l}46 \\
(13.3 \%)\end{array}$ & $\begin{array}{l}60 \\
(17.3 \%)\end{array}$ & $\begin{array}{l}209 \\
(60.4 \%)\end{array}$ & \\
\hline
\end{tabular}

Source (Survey data, 2018)

Majority $(70.8 \%)$ of the households were male headed. On the other hand, female headed households comprised $29.2 \%$. This indicates that most of the decisions in the households were made by men. On-farm participation was a major practice with $87.9 \%$ reporting to actively working on their farms for crop production. A small proportion of the respondents $(11.8 \%)$ did not work on their farms. Most $(61.8 \%)$ of the sampled households participated in social group. However, $38.2 \%$ of the respondents did not have group membership. As shown in Table 2, the ANOVA results between the counties revealed significant differences at $1 \%$ level of statistics level.

Based on the results, only a small proportion $(6.1 \%)$ of respondents had no access to credit to support farming. Embu County registered the highest number of farmers who had accessed credit while Makueni had the lowest leading to significant differences between the two counties at $1 \%$ statistical level). Credit was acquired from the various microfinance institutions located within the study areas. The difference in access to credit may be attributed to the reduced proximity to credit facilities. A report by World Bank asserts that improving access to financial services remain essential. Moreover, the report affirmed that physical distance, inability to meet the requirements for an account and paperwork complexity remains bottlenecks to credit access (World Bank, 2014). Results also revealed that $39.6 \%$ of the respondents participated in off-farm activities to sustain their livelihoods. On the other hand, a majority of $60.4 \%$ relied more on the farm activities to derive their rural livelihoods.

\section{Determinants of the decision to propagate Terminalia brownii}

The results (Table 3 ) highlight the factors that influencing the decision of smallholder farmers to domesticate $T$. 
brownii. Five variables that significantly influence the decision to domesticate include; education level of household head, importance of farm to the household income, access to credit, dependency ratio and intercropping. On the other hand, education of the household head, size of the farm and total income for sale of livestock influenced intensity of domestication of T. brownii.

Education of the household head had a positive significance at $5 \%$ statistical level influence on the decision to domesticate T. brownii. The marginal effect implied that an increase in education by one level increased the decision to domesticate by $8.2 \%$ while holding other variables constant (Ceteris paribus). The possible justification was that farmers who have read, heard or trained on T. brownii were more likely to propagate the tree. Therefore, farmers will tend to allocate more resources in order to acquire more seedlings. Consequently, education places a farmer in a better position with regard to access and synthesis of production information translating to more production options with better varieties of trees. The finding is in line with those of Danso-Abbeam et al., 2017; Caswell et al, 2001; Akudugu et al., 2012). The total dependency ratio was found to have significant negative effect at $10 \%$ statistical level on the decision to domesticate T. brownii. An increase in dependency level by unit decreased the decision by $0.3 \%$ (Table 3 ). This implied that dilemma on scarce resources due to inactive economic contribution reduced chances of allocating more resources to propagation of $T$. brownii. Therefore, the poverty levels in the areas might have escalated farmers dropping out of the domestication activities. Intercropping $T$. brownii with other crops such as green pea, cowpeas, beans, maize, and sorghum had a positive effect on decision to domesticate the tree. The marginal effect implied that intercropping management system increased propagation decision by $24.6 \%$ while holding other variable constant (Ceteris paribus). Previous studies have reported that intercropping management system increase total productivity per unit area through maximum land utilization, production factors such as water, light, nutrients and human labor (Lithourgidis et al., 2006; Li et al, 2010). Access to credit for on farm use was found to have a positive significant effect on decision to domesticate T. brownii. The marginal effect value implied that access to credit boosted the decision to domesticate by 28.17 percent. This means that household heads with access to credit were more likely to domesticate T. brownii. Poor households faced challenges to domesticate $T$. brownii. Therefore, improved access to credit will put them in a better financial position to adopt $T$. brownii growing. This result coincide with findings by Lerman, (2004) who observed that credit plays a crucial role in enhancing and linking farmers to networks that facilitate access to information, modern technology and essential inputs in agricultural production. These findings revealed that the contribution of farm activities to the household income had a negative significant effect. An increase in the range of farm importance by one unit decreased the propagation decision of Terminalia by $5.7 \%$, holding other variables constant. The justification for this is that farmers in the sampled households gave priorities to production of other cash crops with short-term production returns thus reducing domestication of $T$. brownii. The significant factors that influence the intensity of domestication of $T$. brownii include education of household head, farm size and total earnings from sale of livestock (Table 3 ).

Table 3.3: Double hurdle on domestication of Terminalia brownii in Eastern Kenya.

\begin{tabular}{|l|l|l|l|l|l|l|l|l|}
\hline & \multicolumn{3}{|c|}{ Probit Model } & \multicolumn{3}{c|}{ Truncated Model } \\
\hline & $\begin{array}{l}\text { Marginal } \\
\text { Effect } \\
\left(\begin{array}{l}\text { Variable } \\
\text { Robust } \\
\text { Std. Err. }\end{array}\right.\end{array}$ & $\mathbf{Z}$ & $\mathbf{P}>\mathbf{z}$ & Coeff & $\begin{array}{l}\text { Rob. } \\
\text { Std Err }\end{array}$ & $\mathbf{Z}$ & $\mathbf{P}>\mathbf{z}$ \\
\hline Age of Household head & -0.0453 & 0.0545 & -0.83 & 0.406 & -0.1916 & 0.1828 & -1.05 & 0.294 \\
\hline Gender of House. Head & 0.0015 & 0.0017 & 0.88 & 0.378 & 0.0029 & 0.0059 & 0.49 & 0.621 \\
\hline On-farm Participation & -0.1213 & 0.0754 & -1.61 & 0.108 & 0.2854 & 0.2346 & 1.22 & 0.224 \\
\hline $\begin{array}{l}\text { Education level of } \\
\text { Hhead }\end{array}$ & 0.0822 & 0.0268 & 3.07 & $0.002^{* *}$ & 0.1682 & 0.0919 & 1.83 & $0.067^{*}$ \\
\hline Household Size & -0.0134 & 0.0105 & -1.28 & 0.200 & 0.0351 & 0.0343 & 1.02 & 0.306 \\
\hline Farm Size & 0.0072 & 0.0049 & 1.45 & 0.146 & 0.0219 & 0.0117 & 1.87 & $0.061^{*}$ \\
\hline Importance of Farm & -0.0576 & 0.0171 & -3.37 & $0.001 * * *$ & -0.0095 & 0.0743 & -0.13 & 0.898 \\
\hline Group Membership & 0.0265 & 0.0471 & 0.56 & 0.573 & -0.1359 & 0.1664 & -0.82 & 0.414 \\
\hline Access to Credit & 0.2817 & 0.0955 & -2.95 & $0.003 * *$ & -0.1171 & 0.5680 & -0.21 & 0.837 \\
\hline Off-farm Participation & 0.0082 & 0.0535 & 0.15 & 0.878 & -0.1245 & 0.1851 & -0.67 & 0.501 \\
\hline $\begin{array}{l}\text { Total } \\
\text { (Livestock) }\end{array}$ & 0.0022 & 0.0010 & 0.88 & 0.381 & 0.0001 & 0.0001 & 1.83 & $0.067^{*}$ \\
\hline Dependency Ratio & -0.0003 & 0.0002 & -1.8 & $0.072^{*}$ & 0.0000 & 0.0006 & 0 & 0.998 \\
\hline Tropical Livestock Unit & 0.0066 & 0.0066 & 1 & 0.317 & 0.0069 & 0.0207 & 0.33 & 0.741 \\
\hline Intercropping & 0.2460 & 0.0440 & 5.59 & $0.000^{* *}$ & 0.2301 & 0.1960 & 1.17 & 0.240 \\
\hline Source (Survey, 2018)
\end{tabular}

Source (Survey, 2018) $* * *$ Significant at 1\%, ** significant at $5 \%$, * significant at $10 \% ; N=346$

Based on the results of this study, the value of VIF was less than 10 , clarifying no problem of multicollinearity (Appendix 1). Breusch Pagans test / Cook Weisberg test for heteroskedasticity in this study was 
insignificant (Prob $>$ chi2 $=0.132)$. Further, the Ramsey RESET test confirmed that there were no omitted variables in the process of analysis ( $\mathrm{Prob}>\mathrm{F}=0.348$ ).

\section{Determinants of the intensity of domestication of Terminalia brownii}

Results revealed that level of education of the household head was significant at $10 \%$ confidence level to influence the intensity of farmers to domesticate $T$. brownii. This implied that more years of formal education translated to opportunities for utilization of production information and further to realize more market opportunities for $T$. brownii products. The findings are consistent with those of Mal et al., (2012). Size of the farm significantly influenced the intensity of domestication at $10 \%$ confidence level. This implies that as farm size increases, the probability of increased intensity of propagation increased. The direction of this relationship affirms with those of Martey et al., (2014) who observed increased levels of commercialization with increased land size. Farmers with large farm size have the capacity to diversify their farm enterprises reducing dependence on livestock. Total income from sale of livestock was found to have a significant influence on the intensity of domestication of $T$. brownii effect at 10\% confidence interval. This indicates that farmers in the study area allocated more resources on domestication of $T$. brownii. This might be through purchase of farm inputs and utilization during intercropping. The findings are in line with those of Omotesho et al., 2016. The correlation analysis revealed a positive relationship between intercropping and total income derived from sale of livestock.

\section{Conclusion and Policy Implication}

This study analyzed the socioeconomic characteristics of T. brownii smallholder farmers in Kitui, Embu, Machakos and Makueni counties. Furthermore, the study aimed at documenting determinants in domestication of T. brownii. The decision and intensity to domesticate $T$. brownii was significantly influenced by socioeconomic characteristics and infrastructure. The results showed that household head level of education, importance of farm to the household income, access to credit, dependency ratio and intercropping influenced decision to domesticate T. brownii. On the other hand, the domestication intensity was significantly influenced by education of the household head, farm size and total earnings from of livestock sales. The results of this study show consistency with other studies on determinants of adoption and intensity of agricultural technology use among the smallholder farmers. The theoretical and empirical approaches that were adopted by this study produced satisfactory results. These results can be used in understanding the factors that underlie the propagation and regeneration of T. brownii in the context of smallholder farmers. Furthermore, this study shows that the domestication and intensity stages are made successively which concurred with previous studies. Future policy directives should target strengthening all the arrays of factors that have a positive influence on domestication of T. brownii.

\section{Reference}

Altieri, M.A., Nicholls, C.I., Henao, A. \& Lana, M.A. (2015). Agro-ecology and the design of Climate Change resilient farming Systems. Agronomy for Sustainable Development, 35, 869-890.

Akpan, S.B., Nkanta, V.S. \& Essien, U.A. (2012). A Double Hurdle Model of Fertilizer Adoption and Optimum Use among farmers in Southern Nigeria. Tropicultura, 4(30), 249-253.

Akudugu, M. A., Guo, M. \& Kwesi, S.D. (2012). Adoption of Modern Agricultural Production Technologies by Farm households in Ghana: What Factors Influence their Decisions? Journal of Biology, Agriculture and Healthcare, 2(3), 1-13.

Awodoyin, R.O., Olubode, O.S., Ogbu, J.U., Balogun, R.B., Nwawuisi, J.U. \& Orji, K.O. (2015). Indigenous Fruit Trees of Tropical Africa: Status, Opportunity for Development and Biodiversity Management. Agricultural Sciences, 6, 31

Asfaw, S., Bekele, S., Franklin, S. \& Messia, H. (2011, September 12). Agricultural technology adoption, seed access constraint and commercialization in Ethiopia. Journal of Development and Agricultural Economics, 3(9), 436-447.

Asmait W., Senait M., Biniam Y., Mehari A., Kamal C. S. \& Gangwar, S. K. (2018). Analysis of Antibacterial and Antifungal Activity of Terminalia Brownii upon Escherichia Coli \& Candida Albicans. 9 (1):73-78

Berhanu, G. \& Swinton, S.M. (2003). Investment in Soil Conservation in Northern Ethiopia: The role of land tenure security and public programme. Journal of Agricultural Economics, 29, 69 - 84.

Caswell, M., Fuglie, K., Ingram, C., Jans, S. \& Kascak, C. (2001). Adoption of agricultural production pratices: Lessons learned from the US Department of Agriculture area studies project. Agriculture Economic Report No. 792, US Department of Agriculture Economic Research Services, Resource Economics Division, Washington, DC.

CIE. (2011) Evaluation of ICRAFs Agroforestrly Food Security Program AFSP 2007-2011. Center for Independent Evaluations, Lilongwe, Malawi.

Covic, N. \& Hendricks, S. (2016). Achieving a Nutrition Revolution for Africa: The road to Healthier Diets and Optimal Nutrition: ReSAKSS Annual Trends and Outlook Report International Food Policy Research Institute, 
Washington D.C, USA, 1-4.

Cragg, J. (1971). Some statistical models for limited dependent variables with application to the demand for. Econometrica, 39, 829-844.

Danso-Abbeam, G., Bosiako, J.A., Ehiakpor, D.S. \& Mabe, F.N. (2017). Adoption of improved maize variety among farm households in the northern region of Ghana, Cogent Economics \& Finance (2017), 5: 1416896.

Enass Y. A. S., Pia F., Ashraf M. A. A., Abdelazim Y. A., Markku K. Marketta S., Olavi L., Mustafa K. M. Fahmi 1,4, Mai H. E. \& Hiba A. A. (2017). LC-MS/MS Tandem Mass Spectrometry for Analysis of Phenolic Compounds and Pentacyclic Triterpenes in Antifungal Extracts of Terminalia brownii (Fresen). Antibiotics 2017, 6, 37; doi:10.3390/antibiotics6040037

Food and Agriculture Organization (FAO). (2017). The State of Food Security and Nutrition in the World 2017. Building Resilience for Peace and Food Security. Food and Agriculture Organization of the United Nations, Rome, Italy.

Francis, M, Jacob O. M., Melissa R. J., Shabana I. K., Babu, L. Tekwani, J.Z., Larry, W \& Ilias, M. (2013): Phytochemical, Antimicrobial and Antiplasmodial Investigations of Terminalia brownii, Nat Prod Commun, 8(6): 761-764.

Garrity, D.P., Akinnifesi, F.K., Ajayi, O.C., Weldesemayat, S.G., Mowo, J.G., Kalinganire, A., Lawarnou, M. \& Bayala, J. (2012). Evergreen Agriculture: A Robust Approach to Sustainable Food Security in Africa. Food Security 2: 197-241

Gebremichael, B. \& Gebremedhin, B. (2014). February). Adoption of improved box hive technology: Analysis of smallholder farmers in Northern Ethiopia. International Journal of Agricultural Economics and Extension, 2(2). 77-82

ICRAF (1992). A selection of useful trees and shrubs for Kenya: Notes on their identification, propagation and management for use by agricultural and pastoral communities. $226 \mathrm{pp}$.

James Roshetko and Bruno Verbist (2000). Tree Domestication; Lecture Note 6. Bogor, Indonesia

Kareru, P. G, Kenji G. M ,Gachanja, A. N, Keriko J. M, \& Mungai G, (2007). Traditional Medicines among the Embu and Mbeere Peoples of Kenya. Afr. J. Trad. CAM (2007) 4 (1): 75 - 86

Katengeza, S.P., Julius, H.M., Girma, T.K., Chloe, S., Augustine, L., Roberto, L.R. \& Wilfred, M. (2012). Drivers of Improved Maize Variety Adoption in Drought prone areas of Malawi. Journal of Development and Agricultural Economics, 4(14), 393 - 403.

Kidane, B., Van, A. T, \& Maesen, L.G., Asfaw, Z. (2014. Use and management of traditional medicinal plants by Maale and Ari ethnic communities in southern Ethiopia. Journal of ethnobiology and ethnomedicine.

Kigen, G.K., Ronoh, H.K., Kipkore, W.K. \& Rotich, J.K. (2013). Current trends of traditional herbal medicine practice in Kenya: a review. Afr J Pharmacol Ther 2 32-7.

Khalid HS, El-Kamali HH, \& Elmanan AA (2007) Trade of Sudanesenatural medicinals and their role in human and wildlife healthcare. Cropwatch Newsletter 10: 1-15.

Kuti Woles I. (2015). Determinants of adoption of improved maize varieties in Osun State, Nigeria. International Journal of Agricultural Economics and Extension, 3(2), 115 - 121.

Lerman, Z., (2004). Policies and institutions for commercialization of subsistence farms in transition countries. Department of Agricultural Economics and Management, Faculty of Agriculture, The Hebrew University, Rehovot 76100, Israel

Li, H., Shen, J., Zhang, F., Marschner, P., Cawthray, G. \& Rengel, Z. (2010).Phosphorus uptake And Rhizosphere properties of intercropped and mono-cropped maize, faba bean, and White Lupine in acidic soil. Biol Fertil Soils. 46:79 - 91

Lithourgidis, A.S., Vasilakoglou, I.B., Dhima, K.V., Dordas, C.A., \& Yiakoulaki, M.D., (2006). Forage yield and quality of common vetch mixtures with oat and triticale in two seeding ratios. Field Crops Res. 99.

Ma, X., Xu, J.C., Luo, Y., Aggrawal, S.P. \& Li, J.T. (2009). Response of hydrological processes to land-coverand climate changes in Kejie watershed, South West China. Hydrological Processes 23, 1179-1191.

Machumi F, Midiwo JO, Jacob MR, Khan SI, Tekwani BL, \& Zhang J, (2013). Phytochemical, antimicrobial and antiplasmodial investigations of Terminalia brownii. Nat Prod Commun 8:761-4.

Mal, P.A., Asif, R.A., Bauer, S. \& Michael, P. S. (2012). Bt Cotton Adoption: A Double-hurdle Approach for North Indian farmers. AgBioForum, 15(3), 294 - 302.

Martey, E., Ramatu, M. A, \& Kuwornu, K. M. (2012). Commercialization of smallholder agriculture in Ghana: A Tobit regression Analysis. African Journal of Agricultural Research Vol. 7(14), pp. 2131-2141.

Maundu, P. \& Tengnas, B. (2005). Useful trees and shrubs for Kenya. Word Agroforestry Centre. Nairobi, Kenya.

Mbiri, W.J., Kasili, S., Kisangau, D.P., Musila, N.M., \& Piero, N.M, (2016). Antinociceptive Properties of Methanolic Bark Extracts of Terminalia brownii in Wistar Rats. J Pain Relief 5: 261. doi:10.4172/21670846.1000261

Mbwambo ZH, Moshi MJ, Masimba PJ, Kapingu MC, \& Nondo RS. (2007). Antimicrobial activity and brine shrimp toxicity of extracts of Terminalia brownii roots and stem. BMC Complementary Altern Med 7:1. 
Mosango, D.M. (2013). Terminalia brownii Fresen. In: Schmelzer, G.H. \& Gurib-Fakim, A. Prota 11(2). Medicinal plants/Plantes médicinales 2. PROTA, Wageningen, Netherlands [Accessed 30 March 2017]

Mutegi, J.M., Mugendi, D.M., Verchot, L.V. \& Kung'u, J.B. (2008). Combining napier grass with leguminous shrubs in contour hedgerows controls soil erosion without competing with crops. Agroforestry systems 74 , $37-49$.

Neufeldt, H., Ian, K.D., Eike, L., Ajaiyi, O.C., Beedy,T., Gebrekirstos, A., Jamnadass, R.H., Konig, K., Sileshi, G.W., Simelton, E., Montes, C.S. \& Weber, J.C. (2012). Climate Change Vulnerability of Agroforestry. ICRAF Working Paper No.143. Nairobi: World Agroforestry Centre.

Omotesho, K.F., Ogunlade, I., Lawal, M.A. \& Kehinde, F.B. (2016). Determinants of Level of Participation of Farmers in Group Activities in Kwara State, Nigeria. Journal of Agricultural Faculty of Gaziosmanpasa University. http://ziraatdergi.gop.edu.tr. 33 (3), 21-27.

Orwa, C., Mutua, A., Kindt, R., Jamnadass, R., \& Anthony, S. (2009). Agroforestree Dtabase: A tree Reference and selection guide version 4.0. World Agroforestry Centre, Kenya.

Pal, S.K. \& Shukla, Y. (2003). Herbal medicine: current status and the future. Asian Pacific J Cancer Prevention 2013;4:281-8. 2.

Sileshi, G.W., Akiniffesi, F.K., Ajayi, O.C. \& Muys, B. (2012). Integration of Legume Trees in maize-based cropping sytems improves Rain-Use Efficieny and Yield Stability under Rainfed Agriculture . Agricultural Water Management 98, 1364 - 1372.

Schmidt, L.H. (2010). Terminalia brownii Fresen. Seed Leafl., 148, 363-374.

Thoria, O. O. (2007), Biological and Toxico Pathological Studies of Terminalia brownii Tree. Ph.D. Thesis, University of Khartoum, Sudan.

Thorlakson, T. \& Neufeldt, H. (2010). Reducing Subsistence farmers vulnerability to Climate Change: Evaluating the Potential contribution of Agroforestrly in Western Kenya. Agricultural Systems.

Von, G.K., Saltzman, A., Birol, E., Wiesmann, D. \& Prasai, N. (2014). Global Hunger Index: The Challenge of Hidden hunger. Deutsche Welthungerhilfe, Bonn, Germany with International Food Policy Research Institute, Washington, D.C, USA and Concern Worldwide, Durblin, Ireland.

World Bank. (2014). Gender Equality and Development: World Development Report 2012. Washington, DC: 2011

Zakaria, H. M., Mainen, J. M., Pax, J. M., Modest. C. K. \& Ramadhani, S. (2007). Antimicrobial activity and brine shrimp toxicity of Terminalia brownii roots and stem. Journal of Complementary and Alternative Medicine, 1: 7-9.

\section{Conflict of Interest}

No potential conflict of interest was reported by the authors.

\section{Acknowledgement}

We acknowledge support from the National Research Fund (NRF) through the Kenya Forestry Research Institute (KEFRI) and implemented by Drylands Eco-Regional Program (Kitui). The authors acknowledge the technical support from the technical staff members in KEFRI Kitui (Mr. E. Kyalo and M. Nzau), field enumerators (F. Nzilu, N. Kadenyi and T. Chulah), Ecosystem Conservators and T. brownii farmers and marketing agents. The authors are equally indebted to the assistant chiefs, chiefs and officials from the Kenya Forest Service in all the study sites

\begin{tabular}{lll}
\multicolumn{2}{l}{ Appendix 1: Multi-collinearity test on some of the inter-items used in the Survey } \\
\hline Variable & VIF & 1/VIF- Tolerance Factor \\
\hline Off-Farm Participation & 1.43 & 0.698445 \\
Education of the Household head & 1.43 & 0.700702 \\
Age of the Household head & 1.25 & 0.800012 \\
Gender of the Household Head & 1.23 & 0.81139 \\
Farm Size & 1.22 & 0.818177 \\
Import of Farm to household income & 1.22 & 0.821349 \\
Dependency Ration & 1.2 & 0.8358 \\
Household Size & 1.15 & 0.872977 \\
Title Ownership & 1.12 & 0.891299 \\
Intercropping & 1.1 & 0.90626 \\
Total income (Livestock) & 1.09 & 0.915129 \\
On farm Participation & 1.07 & 0.931218 \\
Group Membership & 1.06 & 0.945672 \\
Access to Credit & 1.02 & 0.980742 \\
Mean VIF & $\mathbf{1 . 1 9}$ & \\
\hline
\end{tabular}




\section{Appendix 2: Correlation Analysis Matrix of the variables used for Analysis}

correlate Trans1 GendHHead TitleOwnshp AgeHhead OnfarmPart EducHhead HholdSize FarmSize Importoffarm GrpMembership CreditAccess OffarmP $>$ art TotLivestockY DependencyRatio TropLivestUnit Intercropping (obs $=225$ )

\begin{tabular}{|c|c|c|c|c|c|c|c|c|c|c|c|c|c|}
\hline & Trans1 & GendHH $\sim \mathrm{d}$ & Titleo p & AgeHhead & Onfarm t & EducHh $\sim$ d & HholdS e & FarmSize & Import m & $\mathrm{pM} \sim \mathrm{d}$ & iit & & \\
\hline Trans1 & 1.0000 & & & & & & & & & & & & \\
\hline GendHHead & -0.0207 & 1.0000 & & & & & & & & & & & \\
\hline Titleownshp & 0.1844 & 0.1406 & 1.0000 & & & & & & & & & & \\
\hline AgeHhead & 0.0321 & -0.1213 & 0.0516 & 1.0000 & & & & & & & & & \\
\hline OnfarmPart & 0.0536 & 0.0645 & 0.0349 & -0.1731 & 1.0000 & & & & & & & & \\
\hline EducHhead & 0.0314 & 0.2574 & 0.0480 & -0.2840 & -0.0187 & 1.0000 & & & & & & & \\
\hline HholdSize & 0.0419 & 0.1496 & 0.0370 & 0.0570 & -0.0320 & -0.2013 & 1.0000 & & & & & & \\
\hline FarmSize & 0.2214 & 0.1095 & 0.2497 & 0.1943 & -0.0403 & 0.0491 & 0.0766 & 1.0000 & & & & & \\
\hline Importof Farm & -0.1221 & 0.1111 & -0.0944 & -0.1214 & -0.0643 & 0.1697 & -0.0042 & -0.1184 & 1.0000 & & & & \\
\hline GrpMembers $\sim p$ & 0.0095 & -0.0403 & -0.0396 & 0.0070 & -0.0218 & 0.0450 & 0.0251 & -0.0462 & -0.1403 & 1.0000 & & & \\
\hline CreditAccess & -0.0948 & 0.0489 & 0.0775 & 0.0331 & -0.0116 & 0.0412 & -0.0179 & 0.0143 & -0.0028 & 0.0016 & 1.0000 & & \\
\hline OffarmPart & -0.0596 & 0.1761 & -0.1077 & -0.2828 & -0.0870 & 0.3860 & 0.0289 & -0.1124 & 0.3535 & -0.0372 & 0.0354 & 1.0000 & \\
\hline TotLivesto Y & 0.1815 & 0.1335 & -0.0237 & 0.0155 & 0.0718 & 0.0334 & 0.1351 & 0.1608 & -0.1289 & 0.0360 & -0.0030 & -0.0386 & 1.0000 \\
\hline Dependency o & 0.1396 & 0.2147 & 0.0914 & -0.0767 & 0.0921 & -0.0058 & 0.1386 & 0.2140 & -0.0193 & -0.0547 & -0.0730 & -0.0773 & 0.1134 \\
\hline TropLivest & 0.0652 & 0.1268 & 0.1150 & 0.1534 & -0.0648 & 0.2130 & 0.0497 & 0.2418 & -0.0352 & 0.0013 & -0.0252 & -0.0027 & 0.1987 \\
\hline \multirow[t]{2}{*}{ Intercropp g } & 0.1074 & -0.0623 & 0.0524 & 0.0393 & 0.0182 & -0.1126 & 0.0637 & 0.1010 & -0.1440 & 0.1212 & -0.0401 & -0.0740 & 0.0455 \\
\hline & Depend 0 & TropLi $\sim t$ & Interc $\sim g$ & & & & & & & & & & \\
\hline Dependency o & 1.0000 & & & & & & & & & & & & \\
\hline TropLivest 2 t & 0.1160 & 1.0000 & & & & & & & & & & & \\
\hline Intercropp g & 0.1995 & 0.0259 & 1.0000 & & & & & & & & & & \\
\hline
\end{tabular}

Appendixes 3: Post Hoc on Tukey Test for Contrast between Counties

\begin{tabular}{|c|c|c|c|c|}
\hline Household Size & Contrast & Std. Err & $\mathrm{t}$ & $\mathrm{P}>\mathrm{t}$ \\
\hline Kitui vs Embu & 0.7215 & 0.3448 & 2.0900 & 0.1580 \\
\hline Machakos vs Embu & 0.0061 & 0.3396 & 0.0200 & 1.0000 \\
\hline Makueni vs Embu & -0.1695 & 0.3283 & -0.5200 & 0.9550 \\
\hline Machakos vs Kitui & -0.7154 & 0.3428 & -2.0900 & 0.1590 \\
\hline Makueni vs Kitui & -0.8911 & 0.3316 & -2.6900 & 0.0380 \\
\hline Makueni vs Machakos & -0.1756 & 0.3262 & -0.5400 & 0.9500 \\
\hline Farm Size & Contrast & Std. Err. & $\mathrm{t}$ & $\mathrm{P}>\mathrm{t}$ \\
\hline Kitui vs Embu & 1.6046 & 0.9036 & 1.7800 & 0.2870 \\
\hline Machakos vs Embu & 0.4818 & 0.8899 & 0.5400 & 0.9490 \\
\hline Makueni vs Embu & 4.1223 & 0.8603 & 4.7900 & 0.0000 \\
\hline Machakos vs Kitui & -1.1227 & 0.8983 & -1.2500 & 0.5960 \\
\hline Makueni vs Kitui & 2.5178 & 0.8690 & 2.9000 & 0.0210 \\
\hline Makueni vs Machakos & 3.6405 & 0.8548 & 4.2600 & 0.0000 \\
\hline Tropical Livestock Unit & Contrast & Std. Err. & $\mathrm{t}$ & $\mathrm{P}>\mathrm{t}$ \\
\hline Kitui vs Embu & 1.8636 & 0.6168 & 3.0200 & 0.0140 \\
\hline Machakos vs Embu & 1.1394 & 0.6075 & 1.8800 & 0.2400 \\
\hline Makueni vs Embu & 2.2705 & 0.5872 & 3.8700 & 0.0010 \\
\hline Machakos vs Kitui & -0.7243 & 0.6132 & -1.1800 & 0.6390 \\
\hline Makueni vs Kitui & 0.4068 & 0.5931 & 0.6900 & 0.9020 \\
\hline Makueni vs Machakos & 1.1311 & 0.5835 & 1.9400 & 0.2140 \\
\hline Total LivestockY & Contrast & Std. Err. & $\mathrm{t}$ & $\mathrm{P}>\mathrm{t}$ \\
\hline Kitui vs Embu & 2528.0440 & 5774.9380 & 0.4400 & 0.9720 \\
\hline Machakos vs Embu & 5175.2630 & 5687.7920 & 0.9100 & 0.8000 \\
\hline Makueni vs Embu & 14993.710 & 5498.2530 & 2.7300 & 0.0340 \\
\hline Machakos vs Kitui & 2647.2190 & 5741.4960 & 0.4600 & 0.9670 \\
\hline Makueni vs Kitui & 12465.670 & 5553.7910 & 2.2400 & 0.1130 \\
\hline Makueni vs Machakos & 9818.4470 & 5463.1180 & 1.8000 & 0.2760 \\
\hline Dependency Ratio & Contrast & Std. Err. & $\mathrm{t}$ & $\mathrm{P}>\mathrm{t}$ \\
\hline Kitui vs Embu & 24.5641 & 20.4099 & 1.2000 & 0.6250 \\
\hline Machakos vs Embu & -24.2620 & 20.1019 & -1.2100 & 0.6230 \\
\hline Makueni vs Embu & 45.4769 & 19.4320 & 2.3400 & 0.0910 \\
\hline Machakos vs Kitui & -48.8261 & 20.2917 & -2.4100 & 0.0780 \\
\hline Makueni vs Kitui & 20.9128 & 19.6283 & 1.0700 & 0.7110 \\
\hline Makueni vs Machakos & 69.7389 & 19.3078 & 3.6100 & 0.0020 \\
\hline
\end{tabular}

